\title{
Compatibility of Lemongrass Extract with Spodoptera litura Nuclear Polyhedrosis Virus Against Spodoptera litura on Soybean Plants
}

\author{
Nafisatul Afidah ${ }^{1}$, Tutung Hadiastono ${ }^{1}$, Bedjo $^{2}$, Fery Abdul Choliq ${ }^{1 *}$ \\ ${ }^{1}$ Plant Protection Department, Faculty of Agriculture, University of Brawijaya Jl. Veteran, Malang 65145, East Java, Indonesia \\ ${ }^{2}$ Indonesian Legumes and Tuber Crops Research Institute, Jl. Raya Kendalpayak km 8, Malang 65101, East Java, Indonesia
}

Submitted 25 August 2020 Accepted 02 November 2020

Corresponding author Fery Abdul Choliq;

Feryac@ub.ac.id

\section{ABSTRACT}

Armyworm (Spodoptera litura) is an important pest that damages the leaves of soybean. S/NPV is one type of pathogen that has potential as a biocontrol agent to control armyworms because it is specific, selective, and effective. This study aimed to investigate the compatibility between the lemongrass and SINPV in controlling armyworm. The Research was conducted at the Laboratory of Indonesian Legumes and Tuber Crops Research Institute (ILETRI) from February 2016 until April 2016. The study using completely randomized design with 7 treatments and 3 replication with a treatment that consists of control, SINPV-JTM 97C 1,5 × $10^{6}$ $\mathrm{PIB} / \mathrm{ml}, 10 \%$ of lemongrass extract, a combination SINPV-JTM $97 \mathrm{C}$ fixed concentrate of $1,5 \times 10^{6} \mathrm{PIB} / \mathrm{ml}$ with $2.5 \%, 5 \%, 7.5 \%$, and $10 \%$ of lemongrass extract. The results showed that the combination of SINPV-JTM 97C $1.5 \times 10^{6} \mathrm{PIB} / \mathrm{ml}$ with $10 \%$ lemongrass had the highest level of virulence, with $96 \%$ of mortality on larva $100 \%$ on the pupa stage, so that the combination of SINPV and lemongrass extracts was compatible in controlling S.litura.

Keywords: Soybean; S.litura; SINPV; lemongrass oil; compatibility

\section{INTRODUCTION}

Spodoptera litura Fabricius (Lepidoptera: Noctuidae) is one of the important pests that damage soybean (Punithavalli et al., 2014). Yield loss due to $S$. litura pests attack can reach up to $80 \%$ (Marwoto and Suharsono, 2008). Based on these problems, an effective and efficient, and environmentally friendly control effort is needed, such as Spodoptera litura Nuclear Polyhedrosis Virus (S/NPV). SINPV is a type of pathogenic virus that can potentially be a biological agent in controlling armyworm because it is specific, selective, effective for pests that have been resistant to insecticides, and is environmentally safe (Ayyub et al., 2019). However, one of the disadvantages is that
SINPV, which is not formulated with other ingredients, is less effective when compared to that which is formulated; this is caused by reduced viability, stability, and pathogenicity of SINPV (Trisnaningsih and Kartohardjono, 2016). The effectiveness of the SINPV application can increase with formulation techniques by adding chemical compounds such as protective materials against solar radiation, grading, adhesives, antifeedant (stop appetite), and other compatible entomopathogens (Trisnaningsih and Kartohardjono, 2016).

Botanical pesticides are easily made with their environmentally friendly and biodegradable properties to be safe for humans and animals and reduce 
environmental pollution (El-Wakeil, 2013). A combination of vegetable pesticides and SINPV was carried out in a previous study, while the ingredients used as vegetable pesticides were soursop seed extract (Bedjo, 2015). This biopesticide has been known to have several benefits such as Lemongrass Extract (EDS) singly or in combination with plant extracts with insecticidal properties against the pest of Callosobruchus maculatus (Ojebode et al., 2016). This study aimed to investigate the compatibility and the effectiveness of the lemongrass leaf extract combined with SINPV against $S$. litura in soybean plants.

\section{MATERIALS DAN METODS}

The study was conducted at the Laboratory of Indonesian Legumes and Tuber Crops Research Institute (ILETRI) from February 2016 until April 2016. This study used a Completely Randomized Design with seven treatments and was repeated three times (Table 1). Each experimental unit consisted of 10 larvae $\left(3^{\text {rd }}\right.$ instar of $S$. litura larvae)

\section{Rearing of S. litura}

Propagation of test insects was carried out by collected $S$. litura eggs obtained from the field.
Maintenance was carried out in plastic jar containers whose walls were lined with soybean leaves for larvae to hatch. The larvae were kept until they become the third instar. The larvae were moved into a plastic jar $(\mathrm{d}=5 \mathrm{~cm}$ and $\mathrm{h}=5 \mathrm{~cm})$. Each jar contained one $S$. litura larvae. Some larvae are stored and used as a propagation of NPV isolates.

\section{Propagation of SINPV-JTM 97C isolates}

Propagation of SINPV-JTM 97C isolates was done by pounding larvae that had been infected with SINPV-JTM 97C by using mortar and pistil. The larvae were pounded until their bodies were destroyed, and then $1 \mathrm{ml}$ of distilled water was added. The rough suspension was centrifuged at 3000 rpm for 2 minutes using a centrifuge. Then the supernatant was collected and separated by sediment. The supernatant was separated and then centrifuged at $6000 \mathrm{rpm}$ for 20 minutes. The supernatant was again centrifuged in the same steps as before until a clean sludge was obtained. The final precipitate obtained was resuspended with sufficient distilled water. The suspension was diluted to facilitate the calculation of the concentration of Polyhedra Inclusion Bodies (PIBs).

Table 1. Treatment in this study

\begin{tabular}{cl}
\hline Code & \multicolumn{1}{c}{ Treatment } \\
\hline P0 & Control \\
P1 & 10\% lemon grass extract \\
P2 & SINPV $1,5 \times 10^{6} \mathrm{PIB} / \mathrm{ml}$ \\
P3 & SINPV $1,5 \times 10^{6} \mathrm{PIB} / \mathrm{ml}+2.5 \%$ lemongrass extract \\
P4 & SINPV $1,5 \times 10^{6} \mathrm{PIB} / \mathrm{ml}+5 \%$ lemongrass extract \\
P5 & SINPV $1,5 \times 10^{6} \mathrm{PIB} / \mathrm{ml}+7.5 \%$ lemongrass extract \\
P6 & SINPV $1,5 \times 10^{6} \mathrm{PIB} / \mathrm{ml}+10 \%$ lemongrass extract \\
\end{tabular}




\section{Lemongrass Extract}

Lemongrass was separated from the branches and other impurities and then washed thoroughly. Dried lemongrass was blended to become a powder. The lemongrass powder was dissolved with methanol until completely submerged in a ratio of 1: $4(\mathrm{w} / \mathrm{v})$ while stirring with a glass stirring rod. Then shake for $1 \times 24$ hours. The extraction solution was filtered with filter paper. The lemongrass extract was obtained and then concentrated using a rotary vacuum evaporator at $65^{\circ} \mathrm{C}$ repeatedly. The product of the extraction was put into a sealed plastic bottle and stored.

\section{Inoculation of Insects test}

Spodoptera litura larvae were inoculated by feeding soybean leaves, which had been treated with the dipping method. The leaves used as feed are taken from soybean plants 35 days after planting. The leaf died was dipped in suspension at a concentration of $1.5 \times 10^{6} \mathrm{PIBs} / \mathrm{ml}$. Then the leaves were dried and used as larvae died. Each test larvae was incubated in a rectangular palette $(5 \mathrm{~cm}$ diameter).

Percentage of larvae stop eating was observed at $4,8,12,18,22$ hours after application. When observation stopped eating in the larvae that have been treated, the characteristics of the body surface color become dark. The eating activity was reduced and slow movement. Percentage mortality of $S$. litura larvae was observed every day after the application until the $7^{\text {th }}$ day. The characteristics of larvae that die due to NPV are that the body becomes very soft and easily destroyed. The percentage of $S$. litura larvae that become pupae and adults was observed by counting the number of pupa and adults formed after being given treatment.

\section{Data analysis}

The data were analyzed with the $F$ test at the $5 \%$ level and the further tests with the Least Significant Difference (LSD) at the $5 \%$ level by using SPSS software.

\section{RESULTS AND DISCUSSIONS}

\section{Percentage of S. litura larvae that stop eating}

The results showed that the $S$. litura larvae stopped eating at 4 hours after inoculation. In the treatment of $10 \%$ lemongrass extract (P2), the percentage of larvae that stopped eating was $13 \%$ and more significant than P3 up to P6 treatment. While

Tabel 2. Percentage of S. litura larvae that stop eating

\begin{tabular}{cccccc}
\hline \multirow{2}{*}{ Treatment } & \multicolumn{5}{c}{ Number of S. litura (\%) } \\
\cline { 2 - 6 } & 4 HAl & 8 HAl & $\mathbf{1 2 ~ H A l}$ & $\mathbf{1 8 ~ H A l}$ & 22 HAl \\
\hline P0 & $0 \mathrm{a}$ & $0 \mathrm{a}$ & $0 \mathrm{a}$ & $0 \mathrm{a}$ & $0 \mathrm{a}$ \\
P1 & $13 \mathrm{a}$ & $17 \mathrm{a}$ & $17 \mathrm{a}$ & $43.3 \mathrm{~b}$ & $100 \mathrm{c}$ \\
P2 & $3 \mathrm{a}$ & $3 \mathrm{a}$ & $7 \mathrm{a}$ & $63.3 \mathrm{~cd}$ & $90 \mathrm{~b}$ \\
P3 & $3 \mathrm{a}$ & $10 \mathrm{a}$ & $23 \mathrm{a}$ & $63.3 \mathrm{~cd}$ & $100 \mathrm{c}$ \\
P4 & $0 \mathrm{a}$ & $3 \mathrm{a}$ & $7 \mathrm{a}$ & $56.6 \mathrm{c}$ & $93.3 \mathrm{bc}$ \\
P5 & $10 \mathrm{a}$ & $10 \mathrm{a}$ & $13 \mathrm{a}$ & $60 \mathrm{c}$ & $100 \mathrm{c}$ \\
P6 & $17 \mathrm{a}$ & $20 \mathrm{a}$ & $20 \mathrm{a}$ & $73.3 \mathrm{~d}$ & $100 \mathrm{c}$ \\
\hline
\end{tabular}

Note: P0: Control, P1: $10 \%$ lemongrass extract, P2: SINPV-JTM 97C $1.5 \times 10^{6} \mathrm{PIB} / \mathrm{ml}, \mathrm{P} 3$ SINPV-JTM 97C $1.5 \times 10^{6} \mathrm{PIB} / \mathrm{ml}$ and $2.5 \%$ lemongrass extract, P4: SINPV-JTM 97C $1.5 \times 10^{6} \mathrm{PIB} / \mathrm{ml}$ and $5 \%$ lemongrass extract, P5: SINPV-JTM $97 \mathrm{C} 1.5 \times 10^{6} \mathrm{PIB} / \mathrm{m}$ and $7,5 \%$ lemongrass extract, P6: S/NPV-JTM 97C $1 \mathrm{~b}$ vv.5 $\times 10^{6} \mathrm{PIB} / \mathrm{ml}$ and $10 \%$ lemongrass extract and HAI (Hour After Inoculation). The data is transformed by the arcsin transformation formula $\sqrt{ } x+0.5$ and the numbers followed by the same letters in the same column show no significant difference at the $5 \%$ level of LSD test 

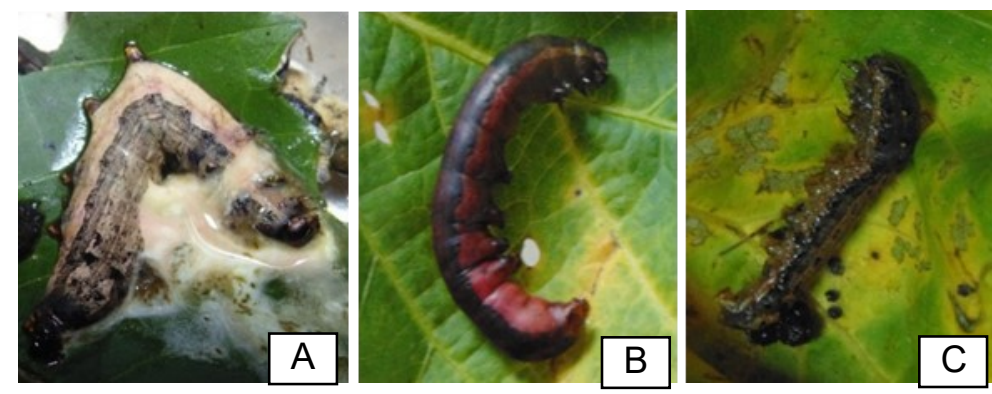

Figure 1. Differences in mortality symptoms of $S$. litura larvae, (a) SINPV-JTM 97C, the larvae hang in an inverted "v" shape and secrete NPV, (b) a combination of SINPV-JTM 97C with lemongrass extract, reddish black larvae, and (c) lemongrass extract, shriveled and thin larvae.

the combination of SINPV-JTM 97C concentration $1.5 \times 10^{6} \mathrm{PIB} / \mathrm{ml}$ with $10 \%$ lemongrass extract (P7) was $17 \%$ and showed the highest value in all treatments (Table 1). These results were changed at 18 hours after inoculation, with the highest percentage in the combination of SINPVJTM 97C concentration $1.5 \times 10^{6} \mathrm{PIB} / \mathrm{ml}$ with $10 \%$ lemongrass extract (P7). Each treatment showed a significant increase in the number of larvae to stop eating. After 22 hours after inoculation in $\mathrm{P} 1$ up to $\mathrm{P} 6$ treatment showed no significant difference (Table 2). The percentage value of larvae stopped eating was more significant than a single SINPV treatment. It showed the existence of synergism between SINPV and lemon extract. Compatibility occurred when SINPV and Lemongrass extract was combined. A factor causing incompatibility between the two solutions was that Lemongrass extract has repellent properties (repellent). According to Ganjewala and Luthra (2009), Cymbopogon essential oils and constituents containing citral compounds (a mixture of geranial and neral) have been known to act as insecticides and insect repellents for a relatively long period. As a result of nature (repellent) possessed by fragrant lemongrass, the larvae had little or no eating the leaves given a combination treatment with SINPV so that the amount of polyhedral ingested and entering the body of the larvae were small.

\section{Mortality of S. litura larva}

The results showed that Spodoptera litura larvae mortality demonstrated a significant effect compared to control, where each treatment

Table 3. Percentage mortality of $S$. litura larvae

\begin{tabular}{cccccccc}
\hline \multirow{2}{*}{ Treatment } & \multicolumn{7}{c}{ Larvae mortality (\%) } \\
\cline { 2 - 7 } & 24 HAl & 48 HAl & 72 HAl & 96 HAl & 120 HAl & 124 HAl & 168 HAl \\
\hline P0 & $0 \mathrm{a}$ & $0 \mathrm{a}$ & $0 \mathrm{a}$ & $0 \mathrm{a}$ & $0 \mathrm{a}$ & $0 \mathrm{a}$ & $0 \mathrm{a}$ \\
P1 & $10 \mathrm{bc}$ & $20 \mathrm{c}$ & $27 \mathrm{~d}$ & $40 \mathrm{c}$ & $63.3 \mathrm{~b}$ & $73 \mathrm{~b}$ & $73 \mathrm{ab}$ \\
P2 & $7 \mathrm{ab}$ & $7 \mathrm{ab}$ & $10 \mathrm{bc}$ & $20 \mathrm{ab}$ & $56.6 \mathrm{~b}$ & $86 \mathrm{~b}$ & $86 \mathrm{~b}$ \\
P3 & $0 \mathrm{a}$ & $3 \mathrm{ab}$ & $10 \mathrm{bc}$ & $20 \mathrm{ab}$ & $63.3 \mathrm{~b}$ & $76.6 \mathrm{~b}$ & $86 \mathrm{~b}$ \\
P4 & $0 \mathrm{a}$ & $3 \mathrm{ab}$ & $7 \mathrm{ab}$ & $30 \mathrm{bc}$ & $73.3 \mathrm{~b}$ & $80 \mathrm{~b}$ & $90 \mathrm{c}$ \\
P5 & $0 \mathrm{a}$ & $17 \mathrm{bc}$ & $23 \mathrm{~cd}$ & $40 \mathrm{c}$ & $66.6 \mathrm{~b}$ & $83.3 \mathrm{~b}$ & $90 \mathrm{c}$ \\
P6 & $17 \mathrm{c}$ & $30 \mathrm{c}$ & $33 \mathrm{~d}$ & $46.6 \mathrm{~d}$ & $73.3 \mathrm{~b}$ & $86.6 \mathrm{~b}$ & $96 \mathrm{c}$ \\
\hline
\end{tabular}

Note: P0: Control, P1: $10 \%$ lemongrass extract, P2: SINPV-JTM 97C $1.5 \times 10^{6} \mathrm{PIB} / \mathrm{ml}, \mathrm{P} 3:$ SINPV-JTM $97 \mathrm{C} 1.5 \times 10^{6}$ $\mathrm{PIB} / \mathrm{ml}$ and $2.5 \%$ lemongrass extract, P4: S/NPV-JTM 97C $1.5 \times 10^{6} \mathrm{PIB} / \mathrm{ml}$ and $5 \%$ lemongrass extract, P5: S/NPV-JTM 97C $1.5 \times 10^{6} \mathrm{PIB} / \mathrm{ml}$ and $7,5 \%$ lemongrass extract, P6: SINPV-JTM 97C $1 \mathrm{~b}$ vv.5 $510^{6} \mathrm{PIB} / \mathrm{ml}$ and 10 $\%$ lemongrass extract and HAI (Hour After Inoculation). The data is transformed by the arcsin transformation formula $\sqrt{ } x+0.5$ and the numbers followed by the same letters in the same column show no significant difference at the $5 \%$ level of LSD test 
showed a percentage value above $85 \%$ at 124 and $168 \mathrm{HAl}$ (Table 3). Combination treatment with $10 \%$ lemongrass extract showed the highest mortality rate of $S$. litura larvae. These results prove that the addition of lemongrass extract affects the NPV as the dose is added. On the $6^{\text {th }}$ day after inoculation, the larvae were died with thick liquid coming out from its body and hanging to form an inverted "V." According to Bedjo (2017), the body of dead larvae will rupture and secrete a thick milk-brown liquid, which is NPV fluid and smells very unpleasant (Figure 1a). In a combination of NPV and Lemongrass extract, larval death symptoms still show characteristics of being infected with the NPV virus, i.e., the larval body looks reddish (Figure 1b). While the larvae that die due to single body lemongrass treatment, the body looks shiny, shrunken, and thin.

\section{Percentage of Pupa Formed}

The results showed that the pupae formed was slow in all treatment compared to the control (Table 4), which means that NPV and Lemongrass extract's larvae cause their life cycle to be longer. According to Hikal, Baeshen, \& Said-Al Ahl (2017), the inhibition of toxic compounds found in botanical pesticides can disrupt the work system that regulates insects' development and metamorphosis. The pupa formed is an abnormal pupa with black, puckered, and some rotten pupa colors. That is due to the death of the pupa before becoming an imago. It proves that NPV that is ingested and enters the larva's body can continue until the pupal stage but causes abnormalities. As a result, the tissue is damaged, which causes changes in pupa shape. Furthermore, according to Bedjo (2017a), pupae infected with SINPV at first the abdomen changes color to grayish-white, then the abdominal skin will become soft and cracked, and turbid fluid containing polyhedral comes out.

\section{Percentage of Adults Formed}

The results showed that $S$ litura adults showed an imago formed in a single 10\% lemongrass treatment, a combination treatment of SINPV-JTM $97 \mathrm{C}$ concentration of $1.5 \times 10^{6} \mathrm{PIB} / \mathrm{ml}$ with lemongrass $(2.5 \%$ and $5 \%)$. The observations showed that larvae infected with SINPV-JTM 97C could still live up to the imago stage even though their growth was longer than that of the control. Adults that appear in the treatment have a normal form. It might be caused by the SINPV-JTM 97C dose applied is the middle dose, i.e., at a concentration of $1.5 \times 106 \mathrm{PIB} / \mathrm{ml}$ so that the amount of

Table 4. Percentage of pupae formed in S. litura larvae

\begin{tabular}{ccccc}
\hline \multirow{2}{*}{ Treatment } & \multicolumn{4}{c}{ Formed pupae (\%) } \\
\cline { 2 - 5 } & 9 DAl & 10 DAl & 11 DAl & 12 DAl \\
\hline P0 & $20 \mathrm{~b}$ & $40 \mathrm{~b}$ & $67 \mathrm{~b}$ & $90 \mathrm{~b}$ \\
P1 & $0 \mathrm{a}$ & $0 \mathrm{a}$ & $7 \mathrm{a}$ & $17 \mathrm{a}$ \\
P2 & $0 \mathrm{a}$ & $0 \mathrm{a}$ & $7 \mathrm{ab}$ & $3 \mathrm{a}$ \\
P3 & $0 \mathrm{a}$ & $0 \mathrm{a}$ & $0 \mathrm{a}$ & $7 \mathrm{a}$ \\
P4 & $0 \mathrm{a}$ & $0 \mathrm{a}$ & $3 \mathrm{a}$ & $3 \mathrm{a}$ \\
P5 & $0 \mathrm{a}$ & $0 \mathrm{a}$ & $0 \mathrm{a}$ & $3 \mathrm{a}$ \\
P6 & $0 \mathrm{a}$ & $0 \mathrm{a}$ & $3 \mathrm{a}$ & $3 \mathrm{a}$ \\
\hline
\end{tabular}

Note: P0: Control, P1: 10 \% lemongrass extract, P2: SINPV-JTM 97C $1.5 \times 10^{6}$ PIB/ml, P3: SINPV-JTM 97C $1.5 \times 10^{6}$ $\mathrm{PIB} / \mathrm{ml}$ and $2.5 \%$ lemongrass extract, P4: SINPV-JTM 97C $1.5 \times 10^{6} \mathrm{PIB} / \mathrm{ml}$ and $5 \%$ lemongrass extract, P5 SINPV-JTM 97C $1.5 \times 10^{6} \mathrm{PIB} / \mathrm{ml}$ and 7,5\% lemongrass extract, P6: S/NPV-JTM 97C $1 \mathrm{~b}$ vv.5 $\times 10^{6} \mathrm{PIB} / \mathrm{ml}$ and 10 $\%$ lemongrass extract and HAI (Hour After Inoculation). The data is transformed by the arcsin transformation formula $\sqrt{x}+0.5$ and the numbers followed by the same letters in the same column show no significant difference at the $5 \%$ level of LSD test 
According to Asri, Rasminah, Rahardjo, \& Sumitro (2013), in their development, the host individual can escape NPV infection's influence with the mechanism of "maturation resistance," in line with age will increase resistance or decrease sensitivity to NPV. The peritrophic membrane as a defense mechanism is still functioning optimally against insect pathogens that enter the body (Sanjaya et al., 2011).

\section{CONCLUSIONS}

The combination of S/NPV-JTM 97C with lemongrass extract is compatible on stop eating, mortality, pupa, and adult formation. The combination treatment of SINPV-JTM 97C concentration ( $1.5 \times 106 \mathrm{PIB} / \mathrm{ml}$ with $10 \%$ extract) showed the highest percentage value at stopping eating until the adults compared to the application of SINPV-JTM 97C and single lemongrass. The treatment is compatible and synergistic, so that it is effective in controlling $S$. litura.

\section{REFERENCES}

Asri, M.T., Rasminah, S. C., Rahardjo, B.T, and Sumitro, S.B. 2013. Mechanism of Infection Spodoptera litura Multiple Nucleopolyhedrosis Virus ( SpltMNPV ) on Midgut Epithelial Cell Army Worm (Spodoptera litura) Observed By TEM. Agrivita 35(1): 88-94.

Ayyub, M.B., Nawaz, A., Arif, M.J., and Amrao, L. 2019. Individual and combined impact of nuclear polyhedrosis virus and spinosad to control the tropical armyworm, Spodoptera litura (Fabricius) (Lepidoptera: Noctuidae) cotton in Pakistan. Egypt. J. Biol. Pest Control 29(1): 67. DOI: 10.1186/s41938-019-0170-4.

Bedjo. 2015. JTM 97C Terhadap Larva Helicoverpa armigera. Balai Penelit. Tanam. Aneka
Kacang dan Umbi (Bedjo 2011): 237-243.

Bedjo, S.W.I. 2017a. Integrasi Varietas Tahan dan Bioinsektisida untuk Pengendalian Ulat Pemakan Daun Kedelai Integration of Resistant Variety and Bio-insecticide Application to Control Soybean Leaf-feeding Caterpillar. Penelit. Pertan. Tanam. Pangan 1(3): 243252.

Bedjo. 2017b. The potential of various isolates of Spodoptera litura Nuclear Polyhedrosis Viruses from East Java (Indonesia) to control Spodoptera litura on soybean. Biodiversitas 18(2): 582-588. doi: 10.13057/biodiv/ d180219.

El-Wakeil, N. 2013. Botanical Pesticides and Their Mode of Action. Gesunde Pflanz. 65. doi: 10.1007/s10343-013-0308-3.

Ganjewala, D., and Luthra, R. 2009. Cymbopogon essential oils Chemical compositions and bioactivities. Int. J. Essent. Oil Ther. 3.

Hikal, W., Baeshen, R., and Said-Al Ahl, H. 2017. Botanical insecticide as simple extractives for pest control. Cogent Biol. 3. DOI: 10.1080/23312025.2017.1404274.

Marwoto and Suharsono. 2008. Strategi dan Komponen Teknologi Pengendalian Ulat Grayak (Spodoptera litura). J. Litbang Pertan. 27(4): 131-136.

Ojebode, M., Olaiya, C., Adegbite, A., Karigidi, K., and T. Ale. 2016. Efficacy of Some Plant Extracts as Storage Protectants against Callosobruchus maculatus. J. Biotechnol. Biomater. $\quad 06$. DOI: 10.4172/2155952X.1000217.

Punithavalli, M., Sharma, A.N., and Rajkumar, M.B.. 2014. Seasonality of the common cutworm Spodoptera litura in a soybean ecosystem. Phytoparasitica 42(2): 213-222. DOI: 10.1007/s12600-013-0354-5. 
Sanjaya, Y., Machmudin, and Kurniawati. 2011. Trisnaningsih, T., and A. Kartohardjono. 2016. Kajian histologis infeksi SINPV terhadap be- $\quad$ Formulasi Nuclear Polyhedrosis Virus (NPV) rat badan dan kerusakan membran peritrofik untuk Mengendalikan Ulat Grayak Padi larva Spodopteera litura. Bioteknologi (Vol. (Mythimna separata Walker) pada Tanaman 8, No. 2, 2011): 78-85. http:// Padi. J. Entomol. Indones. 6(2): 86. doi: biosains.mipa.uns.ac.id/C/C0802/ 10.5994/jei.6.2.86.

C080204.pdf. 